\title{
수질오염총량관리계획 수립을 위한 유달율 적용방안 검증 연구 A Study on Verification of Delivery Ratio Methodology for Basic Plan at TPLMs(Total Pollutant Load Management System)
}

\author{
이성준 · 이한필* · 박지형 · 김용석 · 황하선 ${ }^{\dagger}$ \\ Sung Jun Lee · Han Pil Rhee* · Ji Hyung Park · Yong Seok Kim • Ha Sun Hwang ${ }^{\dagger}$ \\ 국립환경과학원 물환경연구부 · *(주)이티워터 \\ Water Environmental Research Department, National Institute of Environmental Research • *ETWATERS Inc.
}

(Received November 24, 2017; Revised December 12, 2017; Accepted December 22, 2017)

\begin{abstract}
The TPLMs is a system to manage the total amount of pollutants discharged from the watershed in order to achieve the target water quality of the river. In this process, the pollutant load can be classified into generation, discharge and delivery load. When using equation 2 , the discharge coefficient should be 1 . In case of using equation 3 , it is considered that the discharge coefficient defined in the Technical Guideline should be applied. The delivery load is calculated as the product of the discharge load and the delivery ratio, and the delivery ratio is defined as the rate at which the pollutant discharged from the watershed reaches a specific point in the stream. In this study, the delivery ratio estimation method proposed by Hwang (2016) was applied to the Yonggang watershed in the Nakdong river. And the input data of QUALKO2 model was generated by using the estimated delivery ratio (equation 3) and the validation study was conducted by comparing with DRave (equation 2). As a result of the study, it is possible to use both the equation 2 and the equation 3, but it is necessary to change the methodology according to the application of the discharge coefficient.
\end{abstract}

Key Words : TPLMs, Discharge Load, Delivery Load, Delivery Ratio, Water Quality Model

요약 : 수질오염총량관리제도(이하 총량제)는 하천의 목표수질을 달성하기 위해 유역에서 배출되는 오염물질의 총량을 관리 하는 제도이다. 유역에서 배출되는 오염물질의 허용총량은 수질모델을 활용하여 산정하며, 이과정에서 오염부하량은 발생, 배 출, 유달부하량으로 구분할 수 있다. 유달부하량은 배출부하량과 유달율의 곱으로 계산되며 유달율은 유역에서 배출된 오염 물질이 하천의 특정지점에 도달하는 비율로 정의된다. 본 연구에서는 $\operatorname{Hwang}(2016)$ 등이 제시한 기준유량 조건의 유달율 추 정방법을 영강유역에 적용하고 QUALKO2 수질모델의 수질 입력자료를 생성하여 기준유량 조건의 유달율 산정방법(식 (3)) 과 평균 개념의 유달율 산정 방법(식 (2))의 비교분석을 통해 유달율 추정방법에 대한 검증 연구를 수행하였다. 연구결과, 유 달율 함수식은 식 (2)와 식 (3) 모두 사용 가능하나, 배출계수 적용에 따라 방법론을 달리할 필요가 있다. 식 (2)를 사용할 경 우는 배출계수를 저수량, 평수량 구분없이 1 로 동일하게 사용해야 하며, 식 (3)을 사용할 경우는 기술지침에서 정한 배출계 수(저수량 0.15 , 평수량 0.5 )를 적용해야 할 것으로 판단된다.

주제어 : 수질오염총량관리제도, 배출부하량, 유달부하량, 유달율, 수질모델

\section{1. 서 론}

수질오염총량관리제도(이하 총량제)는 하천의 목표수질 을 설정하고 각 단위유역별·행정구역별 목표수질을 달성 할 수 있는 오염부하량(이하 허용총량)을 정하여, 유역에서 부터 하천으로 유입되는 오염부하량을 허용총량 이내로 관 리하는 제도이다. 1999 년 한강수계의 경기도 7 개 시· 군에 서 임의제로 도입한 이후, 2002년에는 낙동강, 금강, 영산 강 - 섬진강수계, 2007년에는 진위천수계, 2010년에는 한강 수계의 서울·인천·경기까지 의무제 기반을 마련하여 전 체 지자체의 약 $75 \%$ 가 총량제를 추진하고 있다.

현행 총량제에서는 $\mathrm{BOD}$ 와 T-P를 대상물질로 선정하여 수계별 각 단위유역 말단에 $\mathrm{BOD}$ 는 저수량 조건, T-P는 저 수량 또는 평수량 중 수질이 악화되어 있는 유량 조건을 기준유량으로 정의하고 기준유량 조건에서 달성할 수 있는 목표수질을 설정한다. 그리고 수질모델링을 활용하여 목표
수질을 만족할 수 있는 기준배출부하량을 산정한 후 안전율 을 고려하여 총량관리 계획기간 동안 준수해야하는 허용총 량을 각 단위유역별·지자체별로 할당하는 과정을 거친다.

이 과정에서 오염부하량은 오염물질의 발생, 배출, 유달 의 과정에 따라 구분하여 산정한다. 발생은 어원 그대로 오 염물질의 생성을 의미하고 이렇게 발생된 오염물질이 자연 현상 또는 인위적 처리 등을 통해 유역 또는 공공수역으로 유입되는 것을 배출이라 하며 배출된 오염물질이 수체의 특정지점에 도달하는 것을 유달이라 한다. ${ }^{1}$ 발생부하량은 오염원조사 자료와 원단위를 토대로 산정하며, 배출부하량 은 수질오염총량관리기술지침(이하 기술지침 $)^{2)}$ 에서 정하고 있는 각 오염원그룹의 배출원과 배출경로 등을 고려하여 연 평균 배출부하량으로 산정한다. 기술지침에 따라 산정된 연 평균 배출부하량을 수질모델에 적용하기 위해서는 기준유 량 조건의 배출계수와 유달율을 적용하여 유달부하량을 산 정하고 기준유량 조건에 부합하는 수질모델의 입력자료를 
생성해야 한다.

기준유량 조건의 배출계수는 기술지침에서 저수량 조건 $(0.15)$ 과 평수량 조건( 0.5$)$ 으로 정하여 적용되고 있는 반면, 유달율은 산정방법이 다양하며 총량관리 계획 수립 시 적 용 가능한 구체적 방안에 대한 명확한 가이드라인이 정해 져있지 않아 다양한 유달율 산정 및 적용에 관한 연구를 통해 합리적 유달율 적용방안 제시가 필요한 실정이다. 이 러한 이유로 Hwang 등은 수질오염총량관리계획 수립에 적합한 유달율 산정방법에 관한 연구를 수행한 바 있다.

Hwang 등 $^{3)}$ 은 유달율은 유달부하량을 추정하여 총량관리 계획 수립 시 수질모델의 입력자료로 활용되므로 과소 또 는 과대 산정되면 수질모델 적용 시 무리한 매개변수를 적 용하게 되고, 오염부하량과 하천수질 간의 반응이 비현실 적으로 나타나는 결과를 초래할 수 있다고 하였다. 그 외 국내에서는 Park, Choi, Jung, Park, Kang 등 $^{4-8)}$ 에 의해 유 달율 경험공식과 유역모형을 활용한 유달율 산정방법 관련 연구가 이루어져왔으나, 총량관리 계획 수립과 연계한 연 구는 부족한 실정이다. 특히, 총량관리계획 수립 시 합리적 인 유달율 적용을 위해서는 경험공식으로 산정된 유달회귀 식에 대한 다양한 검증방안으로 수질모델 입력자료 생성결 과와 연계한 비교·검증 연구가 필요하다.

현행 총량제는 기준유량(저수량 또는 평수량) 조건에서 QUAL 계열(QUAL2E, QUALKO, QUALKO2, QUAL-MEV 등)의 하천수질모델을 활용하여 총량관리계획을 수립하고 있다. 따라서 총량관리 계획 수립 시 활용되는 수질모델에 유달율을 적용하기 위해서는 기준유량 조건에 해당되는 유 달율을 산정할 수 있는 방안과 수질모델 적용방안 도출이 필요하다. 따라서 본 연구에서는 낙동강수계 영강유역을 대 상으로 Hwang 등히 이 제시한 총량관리 기준유량 조건의 유 달율 산정방법과 일반적으로 활용되고 있는 평균 유달율 적
용방법에 따른 유달율 및 수질모델 입력자료의 차이를 비 교·분석하여 기준유량 조건의 총량 유달율 추정방법에 대 한 검증연구를 수행하였다.

\section{2. 연구방법}

\section{1. 대상유역}

영강유역은 경상북도 상주시 화북면 속리산에서 발원하 여 문경시, 상주시를 거쳐 낙동강으로 유입되는 하천으로 총량관리 수계구간으로는 영강A 단위유역에 해당된다. 영 강A 단위유역은 영강의 발원지부터 낙동강 합류전 까지 수계구간으로서 유역면적은 $666.94 \mathrm{~km}^{2}$ 이며, 총 13 개의 총 량관리 소유역으로 구성되어 있다. 대상유역의 토지이용 형 태는 전체 토지 중 임야가 $78.0 \%$, 논 $6.7 \%$, 밭 $6.7 \%$, 대지 $4.3 \%$, 기타 $4.4 \%$ 순으로 나타났다(Table 1 ).

영강은 1 개의 총량 단위유역(영강A)으로 구성된 독립 단 위유역의 형태를 나타내고 있으며, 상류에 위치하고 있어 본류에 비해 상대적으로 하수종말처리장 등 대규모 오염원 의 영향을 적게 받는 특성을 나타낸다. 또한 유역 규모 및 소유역 개수 등을 고려했을 때, 각 소유역에서 산정된 배출 부하량이 유달과정을 거쳐 수질모델에 적용되는 일련의 과 정 및 결과를 도출하고 분석하기에 용이한 유역으로 판단 하여 본 연구의 대상유역으로 선정하였다.

Table 1. Characteristics of landuse in the YeonggangA unit watershed (unit : $\mathrm{km}^{2}$ )

\begin{tabular}{ccccccc}
\hline watershed & Upland & Paddy & Forest & Urban & Etc. & Total \\
\hline \hline Yeonggang & 44.37 & 44.72 & 520.18 & 28.62 & 29.05 & 666.94 \\
A & $(6.7 \%)$ & $(6.7 \%)$ & $(78.0 \%)$ & $(4.3 \%)$ & $(4.4 \%)$ & $(100.0 \%)$ \\
\hline
\end{tabular}

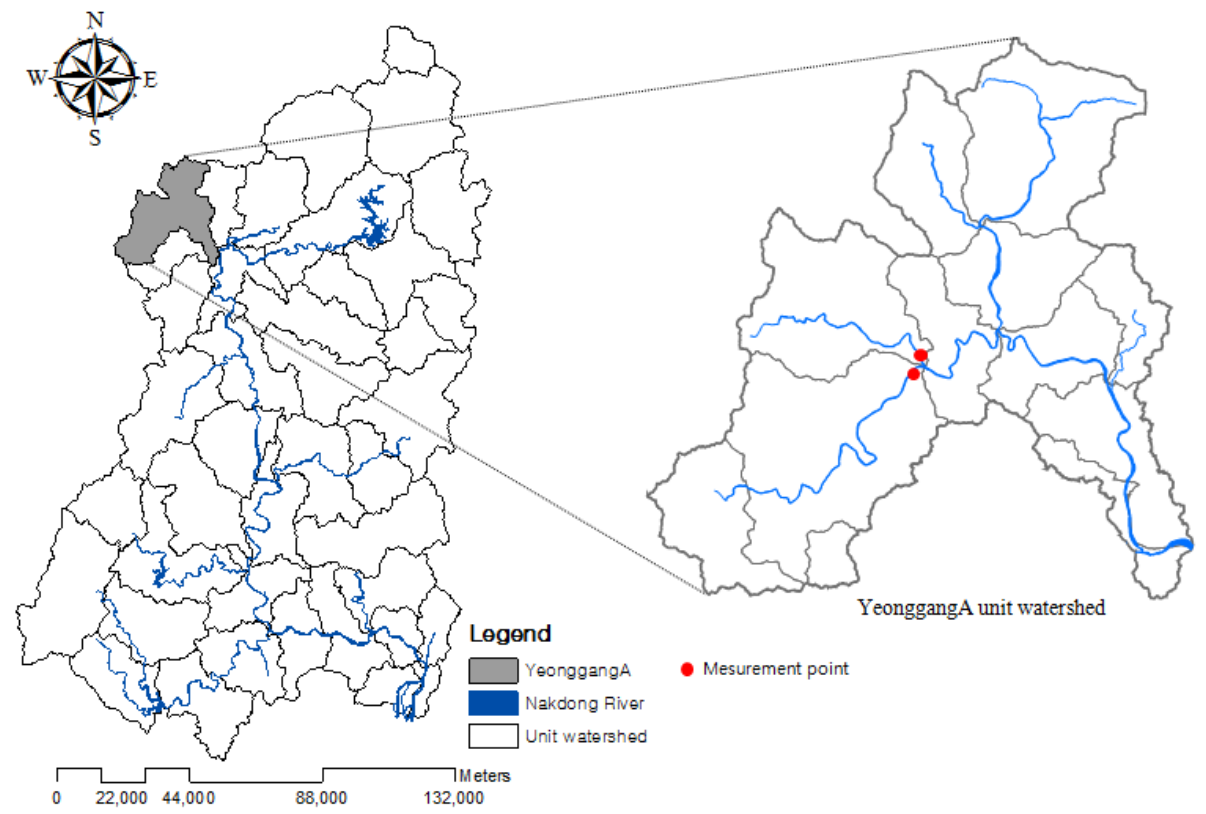

Fig. 1. Location of the YeonggangA watershed in Nakdong river basin. 


\section{2. 실측유달율을 활용한 유달회귀식 도출방법}

\subsection{1. 기초자료 조사}

영강A 단위유역의 소유역별 유달율 산정을 위한 배출부하 량은 제 3 단계 수질오염총량관리 기본계획" 수립 시 2012년 오염원 조사자료를 토대로 산정된 배출부하량을 활용하였다. 실측 유달부하량 산정을 위한 수질 - 유량 조사 자료는 기본 계획 수립 자료 중 하수처리장 등 수계에 직접적인 영향을 주는 주요 오염원이 배제된 영강A01, 영강A02 소유역 말단 에서 44회 실측된 수질·유량 자료를 활용하였다.

\subsection{2. 실측 유달율 산정}

유달율은 유달부하량과 배출부하량의 비로 정의할 수 있 는데, 실측 유달율은 실측 수질·유량 자료로부터 산정된 유달부하량과 기술지침에 따라 산정된 배출부하량을 활용 하여 식 (1)의 방법으로 산정하였다.

$D R_{o b s}=\frac{L_{o}}{L_{c}}=\frac{C_{o} \times Q_{o} \times 86.4}{L_{c}}$

여기서, $\mathrm{DR}_{\mathrm{obs}}=$ 실측 유달율

$$
\begin{aligned}
& \mathrm{L}_{\mathrm{o}}=\text { 실측 유달부하량 }(\mathrm{kg} / \mathrm{day}) \\
& \mathrm{C}_{\mathrm{o}}=\text { 실측 수질농도 }(\mathrm{mg} / \mathrm{L}) \\
& \mathrm{Q}_{\mathrm{o}}=\text { 실측유량 }\left(\mathrm{m}^{3} / \mathrm{sec}\right) \\
& \mathrm{L}_{\mathrm{c}}=\text { 연평균 배출부하량 }(\mathrm{kg} / \mathrm{day})
\end{aligned}
$$

\subsection{3. 유달회귀식 도출}

실측자료가 없는 미계측 소유역 및 기준유량 조건의 유 달율 산정을 위해 소유역 대표 지점(영강A01, 영강A02)의 실측 유달율 산정자료를 활용하여 식 (2) 형태의 유달회귀 식을 도출하였다. 각 소유역별 유량은 단위유역 말단의 기 준유량에 소유역별 면적비를 곱하여 유량-면적비 $(\mathrm{Q} / \mathrm{A})$ 를 산 정하여 적용하였다.

$D R_{t}=a \times\left(\frac{Q_{t}}{A_{t}}\right)^{b}$

여기서, $\mathrm{DR}_{\mathrm{t}}=$ 유량과 면적이 $\mathrm{t}$ 조건일 때 유달율

$\mathrm{Q}_{\mathrm{t}}=\mathrm{t}$ 조건의 유량 $\left(\mathrm{m}^{3} / \mathrm{sec}\right)$

$\mathrm{A}_{\mathrm{t}}=\mathrm{t}$ 조건의 소유역 면적 $\left(\mathrm{km}^{2}\right)$

$\mathrm{a}=$ 상수

$\mathrm{b}=$ 지수

\section{3. 기준유량 조건의 유달율 추정}

총량제 기술지침에서는 수질모델링 등을 수행하기 위한 특정유량조건(저수량 또는 평수량)의 배출계수를 적용하고 있다. 따라서 저수량 및 평수량의 기준유량 조건에서 유달 율을 산정하기 위해 특정유량 조건의 배출계수를 고려하여 Hwang 등 $^{3}$ 이 제시한 식 (3) 형태의 유달율 산정방안을 적
용하여 기준유량 조건의 유달율을 추정하였다.

$$
\begin{aligned}
& D R_{s f}=\frac{D E L \operatorname{Load}_{s f}}{D I S \operatorname{Load}_{s f}} \\
& =\frac{Q_{s f} \times C_{s f} \times 10^{-3}}{\left(\text { GENLoad }_{\text {avg }} \times \alpha_{\text {avg }}\right) \times \beta_{s f}(=1.0 \text { or } 0.15 \text { or } 0.5)}
\end{aligned}
$$

여기서, $\mathrm{DR}_{\mathrm{sf}}=$ 기준유량 조건의 유달율

DEL $\operatorname{Load}_{\mathrm{sf}}=$ 기준유량 조건 유달부하량 $(\mathrm{kg} / \mathrm{day})$

DIS $\operatorname{Load}_{\mathrm{sf}}=$ 기준유량 조건 배출부하량 $(\mathrm{kg} / \mathrm{day})$

$\mathrm{Q}_{\mathrm{sf}}=$ 기준유량 조건 유량 $\left(\mathrm{m}^{3} / \mathrm{sec}\right)$

$\mathrm{C}_{\mathrm{sf}}=$ 기준유량 조건 농도 $(\mathrm{mg} / \mathrm{L})$

$\mathrm{GENLoad}_{\mathrm{avg}}=$ 연평균 일일 발생부하량 $(\mathrm{kg} / \mathrm{day})$

$\alpha_{\text {avg }}=$ 삭감비

$\beta_{\mathrm{sf}}=$ 기준유량(Standard Flow)조건의 배출계수

식 (3)의 기본가정은 첫째, 소유역은 하나의 배출원이며 소유역내 모든 배출원은 동일한 유달특성을 가진다. 둘째, 유달율 산정을 위한 유달부하량은 측정자료가 유달과정을 충분히 대변한다. 셋째, 기준유량 조건의 배출부하량은 기 술지침에서 정하고 있는 배출계수를 사용한다라는 것을 기 본 가정으로 한다. 여기서 배출계수는 점 배출인 경우 저 수, 평수 모두 1.0 이며, 비점 배출인 경우 저수는 0.15 , 평 수는 0.5 로 기술지침에서 정하고 있다.

\section{4. 추정 유달율의 수질모델 적용성 평가}

\subsection{1. 수질모델 구축}

식 (3)에서 제시한 기준유량 조건의 유달율 산정방법과 식 (2)에서 제시한 평균 개념 유달율 산정방법의 적용방안 에 따라 유달율, 유달부하량 및 수질모델에 입력되어지는 수질농도의 차이를 확인하기 위해 수질모델을 구축하였다.

수질모델은 영강A 단위유역에 QUAL계열 모델인 QUALKO2 (NIER, 2007)모델을 적용하였으며, 수질모델 구간은 Element $1 \mathrm{~km}$ 간격으로 Reach 9 개의 구간으로 구분하였다. 수질모 델의 주요 유·출입 오염원인 소유역 13 개, 농업취수 5 개, 점촌하수처리장 등 환경기초시설 3 개소의 분포를 고려하 여 수질모델을 구축(Fig. 2)하고 입력자료를 도출하였다.

\subsection{2. 수질모델 입력자료 도출방법}

수질모델의 입력자료는 기술지침에 따라 산정된 배출부 하량을 식 (4)와 같이 기준유량 조건의 유달율과 배출계수 를 고려하여 유달부하량으로 전환 후 식 (5)와 같이 해당 유 량조건에 대한 수질로 환산하여 도출하였다.

$L_{D R}=\left(P+\left(N P \times \beta_{s f}\right)\right) \times D R_{s f}$

여기서, $\mathrm{L}_{\mathrm{DR}}=$ 기준유량 조건의 유달부하량 $(\mathrm{kg} / \mathrm{day})$ $\mathrm{P}=$ 점 배출부하량 $(\mathrm{kg} / \mathrm{day})$ 

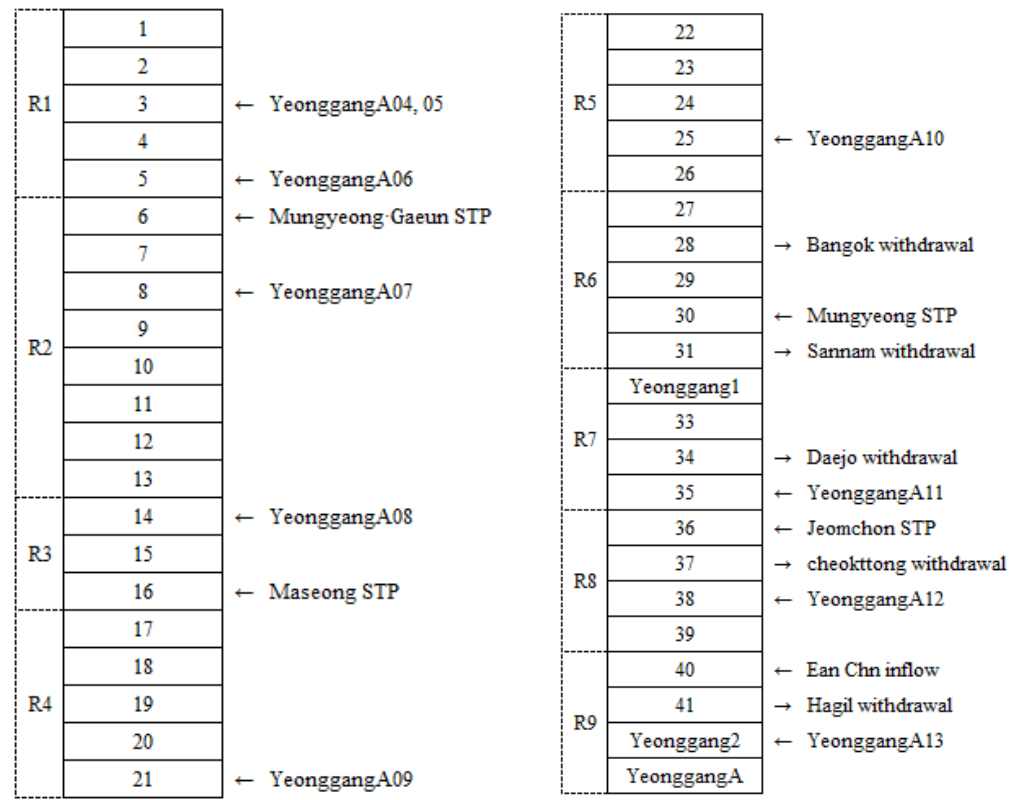

Fig. 2. Stream network of reaches and computational elements (YeonggangA).

$\mathrm{NP}=$ 비점 배출부하량 $(\mathrm{kg} / \mathrm{day})$

$\beta_{\mathrm{sf}}=$ 기준유량(Standard Flow)조건의 배출계수 (저수량 : 0.15 , 평수량 : 0.5 )

$\mathrm{DR}_{\mathrm{sf}}=$ 기준유량 조건의 유달율

$C_{s f}=\frac{L_{D R}}{Q_{s f} \times 86.4}$

여기서, $\mathrm{C}_{\mathrm{sf}}=$ 기준유량 조건의 수질모델 입력농도 $(\mathrm{mg} / \mathrm{L})$

$\mathrm{L}_{\mathrm{DR}}=$ 기준유량 조건의 유달부하량 $(\mathrm{kg} / \mathrm{day})$

$\mathrm{Q}_{\mathrm{sf}}=$ 기준유량 $\left(\mathrm{m}^{3} / \mathrm{sec}\right)$

\subsection{3. 적용성 평가}

식 (3)에서 제시한 기준유량 조건의 유달율 산정방법과 식 (2)에서 제시한 평균 개념의 유달율 산정방법에 따른 배 출계수 적용 시나리오를 Table 2와 같이 4개 Case로 분류· 적용하였다. 점 배출계수는 저수량 및 평수량 조건 모두 1 이며, 비점 배출계수는 기술지침에서 제시한 저수량 조건 0.15 와 평수량 조건 0.5 로 구분하여 식 (3)과 식 (2) 적용에 따라 구분하였다.

Table 2. Delivery ratio equation and discharge coefficient for applicability evaluation

\begin{tabular}{cccccc}
\hline & \multicolumn{3}{c}{ Discharge coefficient } & \\
\cline { 2 - 5 } Category & \multicolumn{3}{c}{ Point } & \multicolumn{3}{c}{ Non-Point } & Methodology \\
\cline { 2 - 5 } & $\mathrm{Q}_{275}$ & $\mathrm{Q}_{185}$ & $\mathrm{Q}_{275}$ & $\mathrm{Q}_{185}$ & \\
\hline \hline CASE 1 & 1 & 1 & 1 & 1 & DR $_{\mathrm{t}}$, equation (2) \\
CASE 2 & 1 & 1 & 1 & 1 & DR $_{\mathrm{sf}}$, equation (3) \\
CASE 3 & 1 & 1 & 0.15 & 0.5 & DRt, equation (2) $_{\mathrm{t}}$ \\
CASE 4 & 1 & 1 & 0.15 & 0.5 & DR $_{\mathrm{sf}}$, equation (3) \\
\hline
\end{tabular}

\section{3. 결과 및 고찰}

\section{1 오염원 및 오염부하량}

영강A 단위유역의 $\mathrm{BOD}$ 총 배출부하량은 $5,287 \mathrm{~kg} / \mathrm{day}$ 로 오염원 그룹별 분석결과, 토지계 $57.7 \%$, 축산계 $28.8 \%$, 생 활계 $11.2 \%$, 양식계 $2.2 \%$, 산업계 $0.1 \%$ 비율을 차지하고 있는 것으로 분석되었다. 또한, T-P의 총 배출부하량은 314
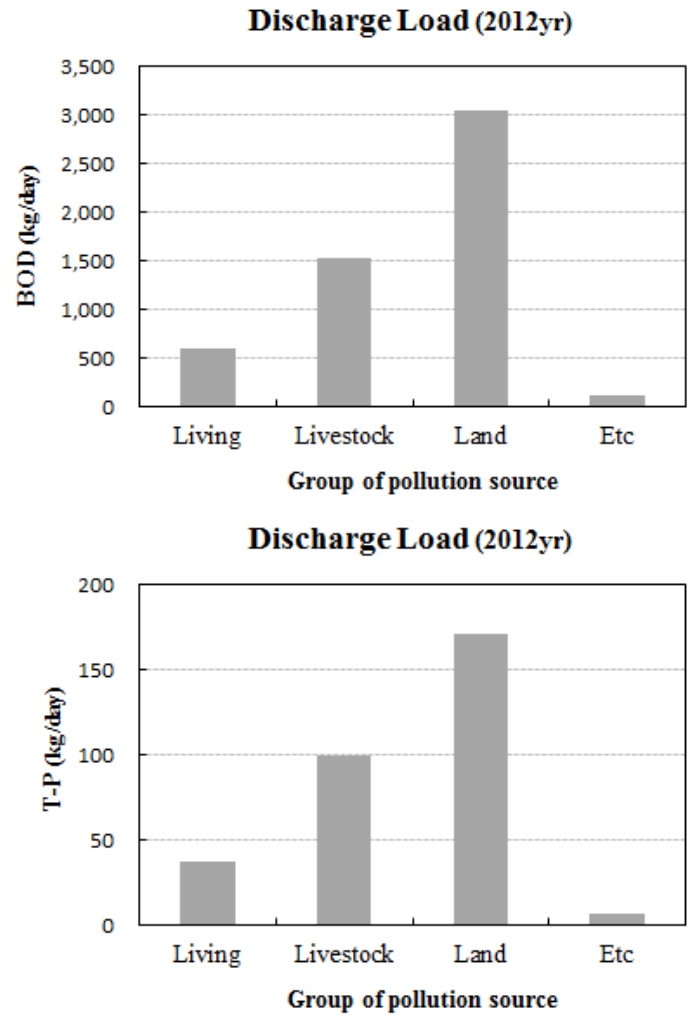

Fig. 3. Status of discharge load (YeonggangA, 2012), 
$\mathrm{kg} / \mathrm{day}$ 로 토지계 $54.3 \%$, 축산계 $31.6 \%$, 생활계 $12.0 \%$, 양식 계 $1.9 \%$, 산업계 $0.2 \%$ 비율을 차지하고 있는 것으로 분석 되었다(Fig. 3).

영강A 단위유역 말단을 기준으로 배출부하량 분석결과, 유역에서 발생 - 배출되는 부하량은 생활계 및 환경기초시 설에 해당하는 점오염원에 비하여 상대적으로 비점오염원 형태로 배출되는 토지계 및 축산계 오염원의 부하량 비중 이 큰 것으로 나타났다. 하지만 이는 유역에서 배출되는 배 출부하량을 의미할 뿐이며, 하천에 미치는 기여율은 각 소 유역별 오염원의 공간적 분포, 유달율, 배출계수 등에 따라 다르게 나타날 수 있을 것으로 판단된다.

\section{2. 실측유달율을 활용한 유달회귀식 도출 결과 3.2.1. 실측 유달율 산정 결과}

유달회귀식 도출을 위해 실측자료와 기술지침에 따라 산 정된 배출부하량을 토대로 식 (1)에 따른 실측유달율 산정 결과는 Table 3과 같으며, 실측유량 $0.301 ~ 5.092 \mathrm{~m}^{3} / \mathrm{sec}$ 범 위에서 산정된 실측 유달율은 BOD 0.018 0.572, T-N 0.067 1.198, T-P 0.011 0.448 범위를 나타냈다(Table 3).

Table 3. Calculation of delivery ratio using measuring data

\begin{tabular}{ccccccc}
\hline \multirow{2}{*}{ Watershed } & \multirow{2}{*}{$\begin{array}{c}\text { Number } \\
\text { of data }\end{array}$} & Category & \multirow{2}{*}{$\begin{array}{c}\text { Flow } \\
\left(\mathrm{m}^{3} / \mathrm{sec}\right)\end{array}$} & \multicolumn{4}{c}{ Delivery ratio } \\
\cline { 5 - 7 } & & & BOD & T-N & T-P \\
\hline \hline \multirow{2}{*}{$\begin{array}{c}\text { Yeonggang } \\
\text { A }\end{array}$} & 44 & Min & 0.301 & 0.018 & 0.067 & 0.011 \\
& & Ave & 1.332 & 0.166 & 0.434 & 0.098 \\
& & Max & 5.092 & 0.572 & 1.198 & 0.448 \\
\hline
\end{tabular}

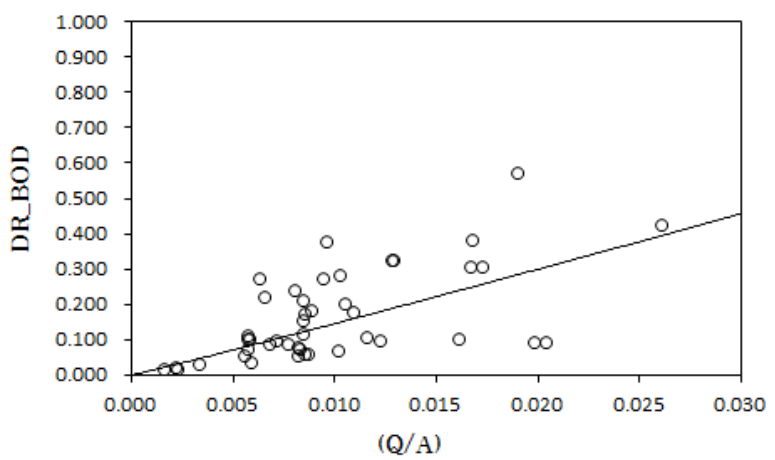

식 (1)에 따른 배출부하량은 기술지침에 따라 연평균 원 단위를 적용하여 산정하였기 때문에 실측 유달율은 연평균 배출부하량 대비 실측 유달부하량의 비로 해석된다. T-N의 경우 $\mathrm{BOD}$ 와 T-P에 비해 유달율의 변동 범위가 크게 나타 났으며, 최대값의 경우는 유달율이 1 을 초과하는 결과 값이 산정되기도 하였다.

유달율이 1 을 초과하는 경우는 실측된 유달부하량이 기 술지침에 따라 산정된 배출부하량 보다 큰 경우를 의미한 다. 이러한 원인을 살펴보면 유달율이 1을 초과하는 시기 의 실측 유량은 $3.362 \sim 5.092 \mathrm{~m}^{3} / \mathrm{sec}$ 범위로써 전체 실측유 량 $0.301 \sim 5.092 \mathrm{~m}^{3} / \mathrm{sec}$ 범위 중 고유량 조건에 포함되어 평 균 개념의 배출부하량에 비해 고유량 조건의 유달부하량이 상대적으로 크게 산정된 것으로 판단된다. Shon 등 ${ }^{10)}$ 의 연 구에 의하면 T-N의 경우 다른 오염원에 비해 유달율의 큰 변동을 나타내는 이유는 지하수 등 기저유출에서 기인하는 질소의 배경농도가 높음에도 불구하고 현행 오염부하량 산 정방식에는 오염물질의 배경농도를 고려할 수 없기 때문이 라고 판단하고 있다.

\subsection{2. 유달회귀식 도출 결과}

실측 유달율을 토대로 식 (2)와 같은 유량-면적비 $(\mathrm{Q} / \mathrm{A})$ 와 평균유달율 $\left(\mathrm{DR}_{\mathrm{ave}}\right)$ 의 관계를 도식화(Fig. 4)하여 거듭제곱 형태의 유달회귀식을 도출한 결과는 Table 4와 같다. 유량면적비 $(\mathrm{Q} / \mathrm{A})$ 와 평균 유달율 간 상관성을 나타내는 결정계 수 $\left(\mathrm{R}^{2}\right)$ 는 T-N 0.90, BOD 0.53, T-P 0.50 순으로 나타났다. Choi 등 ${ }^{5)}$ 의 선행연구에 의하면 결정계수 $\left(\mathrm{R}^{2}\right)$ 가 0.5 0.6 이 상이면 유달율 회귀식의 추세값을 잘 반영한다고 제안하였

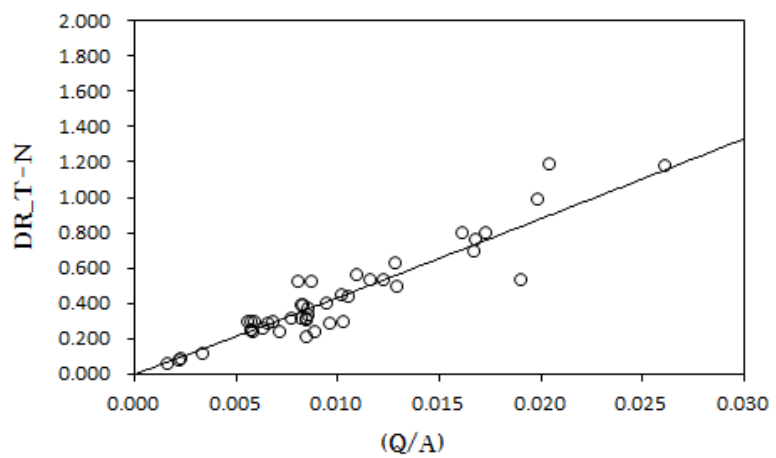

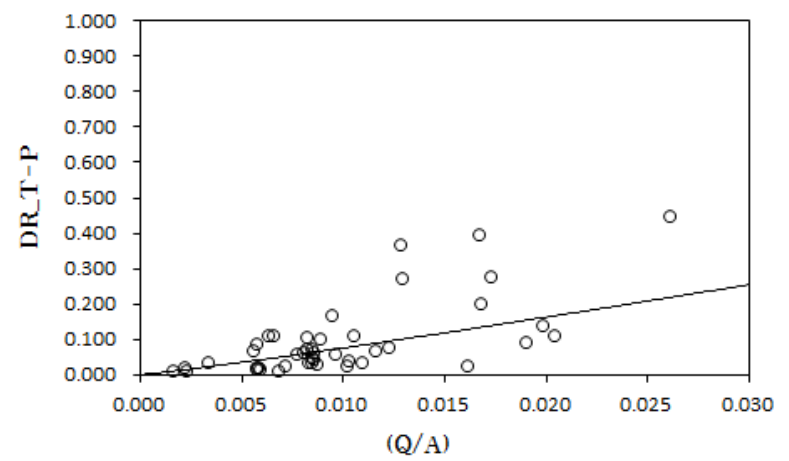

Fig. 4. Relationship between $(\mathrm{Q} / \mathrm{A})$ and DRave at YeonggangA. 
Table 4. Result of regression equations for delivery ratios

\begin{tabular}{ccc}
\hline Pollutant & Equation & $\mathrm{R}^{2}$ \\
\hline \hline BOD & $\mathrm{y}=17.66 \mathrm{x}^{1.0424}$ & 0.53 \\
T-N & $\mathrm{y}=48.596 \mathrm{x}^{1.0255}$ & 0.90 \\
T-P & $\mathrm{y}=12.24 \mathrm{x}^{1.1042}$ & 0.50 \\
\hline
\end{tabular}

으므로 본 연구에서 도출한 유달회귀식의 적용성은 높은 것 으로 판단된다. 유량-면적비 $(\mathrm{Q} / \mathrm{A})$ 와 실측 유달율의 관계를 활용한 유달율 경험공식은 Hwang, ${ }^{3)}$ Park $^{7)}$ 등의 연구에서 도 검증된 바 있다.

도출된 회귀식을 적용하여 소유역별 평균 유달율을 산정 한 결과는 Table 5 와 같으며, 단위유역 내 모든 소유역의 유 달율이 유사한 범위에서 산정되는 결과를 나타냈다. 이러한
원인은 회귀식 적용 시 식 (2)의 회귀식에 입력되는 각 소유 역별 유량-면적비 $(\mathrm{Q} / \mathrm{A})$ 가 영강 $\mathrm{A}$ 단위유역 말단의 기준유량 을 소유역별 면적비로 배분하여 저수량 $\left(\mathrm{Q}_{275}\right)$ 과 평수량 $\left(\mathrm{Q}_{185}\right)$ 을 산정하였기 때문에 단위유역 내 모든 소유역의 유달율이 유사한 범위에서 산정되는 결과를 나타내게 되었다.

\section{3. 기준유량 조건의 유달율 산정결과}

기준유량(저수량 또는 평수량) 조건의 유달율을 산정하 기 위해 기술지침에서 정하고 있는 기준유량의 배출계수를 고려한 식 (3)을 활용하여 유달율을 산정한 결과는 Table 6 과 같다. 식 (2)의 평균개념 유달율 산정결과와 식 (3)의 기 준유량 조건 유달율 산정결과를 비교해보면 전반적으로 평 균유달율로 산정된 결과가 기준유량 조건의 유달율 산정결

Table 5. Result of delivery ratios $\left(\mathrm{DR}_{\text {ave }}\right)$ at standard flow

\begin{tabular}{|c|c|c|c|c|c|c|c|c|c|}
\hline \multirow{3}{*}{ Watershed } & \multirow{3}{*}{$\begin{array}{l}\text { Area } \\
\left(\mathrm{km}^{2}\right)\end{array}$} & \multicolumn{8}{|c|}{ Delivery ratio (DRave) of standard flow } \\
\hline & & \multicolumn{4}{|c|}{$Q_{275}$} & \multicolumn{4}{|c|}{$Q_{185}$} \\
\hline & & Flow & $\mathrm{BOD}$ & $\mathrm{T}-\mathrm{N}$ & $\mathrm{T}-\mathrm{P}$ & Flow & $\mathrm{BOD}$ & $\mathrm{T}-\mathrm{N}$ & $\mathrm{T}-\mathrm{P}$ \\
\hline Y.G_A 01 & 49.34 & 0.169 & 0.048 & 0.144 & 0.023 & 0.461 & 0.135 & 0.403 & 0.070 \\
\hline Y.G_A 02 & 11.65 & 0.040 & 0.048 & 0.144 & 0.023 & 0.109 & 0.136 & 0.404 & 0.070 \\
\hline Y.G_A 03 & 106.47 & 0.364 & 0.047 & 0.144 & 0.023 & 0.995 & 0.135 & 0.403 & 0.070 \\
\hline Y.G_A 04 & 0.84 & 0.003 & 0.050 & 0.151 & 0.024 & 0.008 & 0.139 & 0.413 & 0.072 \\
\hline Y.G_A 05 & 27.03 & 0.092 & 0.047 & 0.143 & 0.023 & 0.253 & 0.136 & 0.404 & 0.070 \\
\hline Y.G_A 06 & 85.73 & 0.293 & 0.047 & 0.144 & 0.023 & 0.801 & 0.135 & 0.403 & 0.070 \\
\hline Y.G_A 07 & 43.17 & 0.147 & 0.047 & 0.143 & 0.023 & 0.403 & 0.135 & 0.403 & 0.070 \\
\hline Y.G_A 08 & 201.68 & 0.689 & 0.047 & 0.144 & 0.023 & 1.884 & 0.135 & 0.403 & 0.070 \\
\hline Y.G_A 09 & 44.11 & 0.151 & 0.048 & 0.144 & 0.023 & 0.412 & 0.135 & 0.403 & 0.070 \\
\hline Y.G_A 10 & 27.66 & 0.094 & 0.047 & 0.143 & 0.023 & 0.258 & 0.135 & 0.402 & 0.070 \\
\hline Y.G_A 11 & 52.28 & 0.179 & 0.048 & 0.144 & 0.023 & 0.488 & 0.135 & 0.403 & 0.070 \\
\hline Y.G_A 12 & 11.06 & 0.038 & 0.048 & 0.144 & 0.023 & 0.103 & 0.135 & 0.402 & 0.070 \\
\hline Y.G_A 13 & 6.87 & 0.023 & 0.046 & 0.141 & 0.023 & 0.064 & 0.135 & 0.402 & 0.070 \\
\hline \multicolumn{2}{|c|}{ Average } & 0.176 & 0.048 & 0.144 & 0.023 & 0.480 & 0.136 & 0.404 & 0.070 \\
\hline
\end{tabular}

Table 6. Result of delivery ratios $\left(\mathrm{DR}_{\mathrm{sf}}\right)$ at standard flow

\begin{tabular}{|c|c|c|c|c|c|c|c|c|c|}
\hline \multirow{3}{*}{ Watershed } & \multirow{3}{*}{$\begin{array}{l}\text { Area } \\
\left(\mathrm{km}^{2}\right)\end{array}$} & \multicolumn{8}{|c|}{ Delivery ratio $\left(\mathrm{DR}_{\mathrm{sf}}\right)$ of standard flow } \\
\hline & & \multicolumn{4}{|c|}{$Q_{275}$} & \multicolumn{4}{|c|}{$Q_{185}$} \\
\hline & & Flow & $\mathrm{BOD}$ & $\mathrm{T}-\mathrm{N}$ & T-P & Flow & BOD & T-N & T-P \\
\hline Y.G_A 01 & 49.34 & 0.169 & 0.156 & 0.667 & 0.092 & 0.461 & 0.229 & 0.748 & 0.125 \\
\hline Y.G_A 02 & 11.65 & 0.040 & 0.160 & 0.752 & 0.109 & 0.109 & 0.231 & 0.769 & 0.131 \\
\hline Y.G_A 03 & 106.47 & 0.364 & 0.167 & 0.706 & 0.099 & 0.995 & 0.234 & 0.758 & 0.128 \\
\hline Y.G_A 04 & 0.84 & 0.003 & 0.160 & 0.728 & 0.098 & 0.008 & 0.233 & 0.773 & 0.129 \\
\hline Y.G_A 05 & 27.03 & 0.092 & 0.212 & 0.799 & 0.121 & 0.253 & 0.250 & 0.781 & 0.134 \\
\hline Y.G_A 06 & 85.73 & 0.293 & 0.188 & 0.734 & 0.107 & 0.801 & 0.242 & 0.765 & 0.130 \\
\hline Y.G_A 07 & 43.17 & 0.147 & 0.192 & 0.511 & 0.074 & 0.403 & 0.243 & 0.699 & 0.118 \\
\hline Y.G_A 08 & 201.68 & 0.689 & 0.201 & 0.633 & 0.089 & 1.884 & 0.246 & 0.739 & 0.125 \\
\hline Y.G_A 09 & 44.11 & 0.151 & 0.240 & 0.800 & 0.122 & 0.412 & 0.256 & 0.778 & 0.134 \\
\hline Y.G_A 10 & 27.66 & 0.094 & 0.234 & 0.817 & 0.125 & 0.258 & 0.255 & 0.782 & 0.135 \\
\hline Y.G_A 11 & 52.28 & 0.179 & 0.150 & 0.251 & 0.056 & 0.488 & 0.226 & 0.537 & 0.107 \\
\hline Y.G_A 12 & 11.06 & 0.038 & 0.250 & 0.829 & 0.131 & 0.103 & 0.257 & 0.781 & 0.136 \\
\hline Y.G_A 13 & 6.87 & 0.023 & 0.137 & 0.663 & 0.093 & 0.064 & 0.221 & 0.749 & 0.126 \\
\hline \multicolumn{2}{|c|}{ Average } & 0.176 & 0.188 & 0.684 & 0.101 & 0.480 & 0.240 & 0.743 & 0.128 \\
\hline
\end{tabular}


과에 비하여 최소 $43 \%$ 최대 $83 \%$ 범위 정도로 적게 산정 된 것으로 나타났다.

식 (2)는 소유역별 유달율이 전체적으로 유사한 범위에서 산정된 반면, 식 (3)의 경우는 점과 비점 배출부하량의 비 율에 따라 소유역별로 유달율이 일부 차이가 나타나는 것 으로 산정되었다. 이러한 원인은 식 (3)의 경우 분모가 되 는 배출부하량에 이미 특정유량조건의 배출계수가 고려될 수 있도록 수식을 구성했기 때문이다. 또한, 식 (3)에 의해 산정된 유달율 결과는 점과 비점 배출부하량의 비율에 따 라 유달율이 다르게 산정되므로 다양한 점, 비점 삭감시나 리오에 따른 유달율 및 유달부하량 변화를 식 (2)에 비하여 합리적으로 해석 가능할 것으로 판단된다.

\section{4. 유달율 적용방안의 검증 평가}

Case 1 4의 산정된 결과 값은 BOD, T-N, T-P 모두 동일 한 경향과 패턴을 나타내었는데 그 중에서 총량제 대상물 질이면서 상대적으로 $\mathrm{BOD}$ 보다 유달율에 민감한 T-P의 결 과를 살펴보면 각 Case에 따라 계산된 유달부하량은 Table 7과 같다. 저수량 및 평수량 조건 둘다 Case2, Case1, 4, Case3의 크기 순으로 산정되었으며, Case1과 Case4는 동일 한 결과 값이 산정되었다.

Table 7에서 산정된 유달부하량 만으로는 Case 1 4에서 산정된 값들의 차이점을 명확하게 확인하기 어려워 산정된 유달부하량을 기준유량으로 나누어 실제 수질모델에 입력 되는 수질농도를 산정하였다(Table 8). 수질모델 입력자료

Table 7. Result of delivery load for applicability evaluation

(unit : $\mathrm{kg} /$ day)

\begin{tabular}{|c|c|c|c|c|c|c|c|c|c|}
\hline \multirow{3}{*}{ Watershed } & \multirow{3}{*}{$\begin{array}{l}\text { Area } \\
\left(\mathrm{km}^{2}\right)\end{array}$} & \multicolumn{8}{|c|}{ Delivery Load (T-P) } \\
\hline & & \multicolumn{4}{|c|}{$Q_{275}$} & \multicolumn{4}{|c|}{$Q_{185}$} \\
\hline & & Case1 & Case2 & Case3 & Case4 & Case1 & Case2 & Case3 & Case4 \\
\hline Y.G_A 01 & 49.34 & 0.257 & 1.016 & 0.065 & 0.257 & 0.778 & 1.388 & 0.436 & 0.778 \\
\hline Y.G_A 02 & 11.65 & 0.071 & 0.331 & 0.015 & 0.071 & 0.215 & 0.399 & 0.115 & 0.215 \\
\hline Y.G_A 03 & 106.47 & 0.915 & 3.926 & 0.213 & 0.915 & 2.777 & 5.060 & 1.524 & 2.777 \\
\hline Y.G_A 04 & 0.84 & 0.006 & 0.026 & 0.002 & 0.006 & 0.019 & 0.034 & 0.010 & 0.019 \\
\hline Y.G_A 05 & 27.03 & 0.259 & 1.366 & 0.049 & 0.259 & 0.793 & 1.514 & 0.415 & 0.793 \\
\hline Y.G_A 06 & 85.73 & 0.472 & 2.187 & 0.102 & 0.472 & 1.433 & 2.660 & 0.772 & 1.433 \\
\hline Y.G_A 07 & 43.17 & 0.399 & 1.287 & 0.124 & 0.399 & 1.215 & 2.045 & 0.722 & 1.215 \\
\hline Y.G_A 08 & 201.68 & 2.137 & 8.259 & 0.553 & 2.137 & 6.488 & 11.505 & 3.659 & 6.488 \\
\hline Y.G_A 09 & 44.11 & 0.618 & 3.236 & 0.118 & 0.618 & 1.871 & 3.570 & 0.980 & 1.871 \\
\hline Y.G_A 10 & 27.66 & 0.339 & 1.847 & 0.062 & 0.339 & 1.033 & 1.988 & 0.537 & 1.033 \\
\hline Y.G_A 11 & 52.28 & 1.604 & 3.865 & 0.666 & 1.604 & 4.855 & 7.402 & 3.185 & 4.855 \\
\hline Y.G_A 12 & 11.06 & 0.161 & 0.905 & 0.029 & 0.161 & 0.485 & 0.939 & 0.251 & 0.485 \\
\hline Y.G_A 13 & 6.87 & 0.041 & 0.169 & 0.010 & 0.041 & 0.128 & 0.230 & 0.071 & 0.128 \\
\hline \multicolumn{2}{|c|}{ Sum } & 7.280 & 28.419 & 2.007 & 7.280 & 22.090 & 38.735 & 12.678 & 22.090 \\
\hline
\end{tabular}

Table 8. Result of model input data for applicability evaluation

(unit : mg/L)

\begin{tabular}{|c|c|c|c|c|c|c|c|c|c|}
\hline \multirow{3}{*}{ Watershed } & \multirow{3}{*}{$\begin{array}{l}\text { Area } \\
\left(\mathrm{km}^{2}\right)\end{array}$} & \multicolumn{8}{|c|}{ Input data of waterquality model (T-P) } \\
\hline & & \multicolumn{4}{|c|}{$Q_{275}$} & \multicolumn{4}{|c|}{$Q_{185}$} \\
\hline & & Case1 & Case2 & Case3 & Case4 & Case1 & Case2 & Case3 & Case4 \\
\hline Y.G_A 01 & 49.34 & 0.018 & 0.070 & 0.004 & 0.018 & 0.053 & 0.095 & 0.030 & 0.053 \\
\hline Y.G_A 02 & 11.65 & 0.005 & 0.023 & 0.001 & 0.005 & 0.015 & 0.027 & 0.008 & 0.015 \\
\hline Y.G_A 03 & 106.47 & 0.063 & 0.269 & 0.015 & 0.063 & 0.190 & 0.347 & 0.104 & 0.190 \\
\hline Y.G_A 04 & 0.84 & 0.001 & 0.002 & 0.001 & 0.001 & 0.001 & 0.002 & 0.001 & 0.001 \\
\hline Y.G_A 05 & 27.03 & 0.018 & 0.094 & 0.003 & 0.018 & 0.054 & 0.104 & 0.028 & 0.054 \\
\hline Y.G_A 06 & 85.73 & 0.032 & 0.150 & 0.007 & 0.032 & 0.098 & 0.182 & 0.053 & 0.098 \\
\hline Y.G_A 07 & 43.17 & 0.027 & 0.088 & 0.008 & 0.027 & 0.083 & 0.140 & 0.049 & 0.083 \\
\hline Y.G_A 08 & 201.68 & 0.146 & 0.566 & 0.038 & 0.146 & 0.444 & 0.788 & 0.251 & 0.444 \\
\hline Y.G_A 09 & 44.11 & 0.042 & 0.222 & 0.008 & 0.042 & 0.128 & 0.245 & 0.067 & 0.128 \\
\hline Y.G_A 10 & 27.66 & 0.023 & 0.126 & 0.004 & 0.023 & 0.071 & 0.136 & 0.037 & 0.071 \\
\hline Y.G_A 11 & 52.28 & 0.110 & 0.265 & 0.046 & 0.110 & 0.333 & 0.507 & 0.218 & 0.333 \\
\hline Y.G_A 12 & 11.06 & 0.011 & 0.062 & 0.002 & 0.011 & 0.033 & 0.064 & 0.017 & 0.033 \\
\hline Y.G_A 13 & 6.87 & 0.003 & 0.012 & 0.001 & 0.003 & 0.009 & 0.016 & 0.005 & 0.009 \\
\hline \multicolumn{2}{|c|}{ Average } & 0.038 & 0.150 & 0.011 & 0.038 & 0.116 & 0.204 & 0.067 & 0.116 \\
\hline
\end{tabular}


산정 결과, 저수량 및 평수량 조건 둘다 Case2, Case1, 4, Case3의 크기 순으로 산정되었으며, Case1과 Case4는 동일 한 결과 값이 산정되었다.

Case1과 Case4에 적용된 유달율 산정식이 다르지만 결 과값이 동일하게 산정된 이유는 적용된 배출계수의 적용에 따른 차이 때문인 것으로 나타났다. Case1은 평균적 유달 율 개념이 적용된 상황에서 배출계수를 1 로 적용한 것이 고, Case4는 기준유량 조건의 유달율 산정에 배출계수 저 수량(0.15), 평수량 $(0.5)$ 을 고려해줬지만 이미 식 (3) 자체에 기술지침에 따른 배출계수를 정의하고 있었기 때문에 산정 식은 다르지만 적용과정에서 배출계수의 작용으로 동일한 값이 산정되었다.

산정된 수질농도 값의 재현성을 비교해보면 Case 1, 4에 비해 Case 2는 과대 산정되었으며, Case 3은 과소 산정된 것을 알 수 있다. 그리고 영강A 단위유역 말단의 2012년 평균 T-P 수질이 $0.039 \mathrm{mg} / \mathrm{L}$ 인 것을 감안하면 Case 1,4 에 서 산정된 수질농도의 평균값은 $0.038 \mathrm{mg} / \mathrm{L}(0.009 \sim 0.207$ $\mathrm{mg} / \mathrm{L}$ )로 Case 2, 3에 비해 합리적으로 산정된 것을 알 수 있다.

또한, Table 8의 수질모델 입력자료 결과를 살펴보면 모 델 적용 시 Case 2는 입력자료가 과대하게 산정되어 모델 매개변수의 과도한 침전 기작을 조정해야 하며, Case 3 는 입력자료가 과소하게 산정되어 모델 매개변수의 과도한 용 출 기작을 조정해야 보 - 검증이 되는 상황이 발생할 것으 로 판단된다. 하지만 이렇게 무리한 매개변수로 보·검증 된 모델은 유역의 배출부하량 값이 변하더라도 수질모델의 반응정도가 둔감하기 때문에 다양한 시나리오를 토대로 목 표수질 및 계획수립에 적용하기에 적합하지 않을 것으로 판단된다.

\section{4. 결 론}

본 연구에서는 낙동강수계 영강유역을 대상으로 Hwang 등 $^{3)}$ 이 제시한 총량관리 기준유량 조건의 유달율 산정방법 과 평균 유달율 산정방법에 따른 차이를 비교·분석하여 기준유량 조건의 유달율 추정방법에 대한 적용성을 평가하 고 검증하였으며 주요 결과 및 결론은 다음과 같다.

1) 실측유달율을 활용하여 유달회귀식을 산정한 결과, T-N 은 일부 고유량 조건의 실측자료에서 유달부하량과 배출부 하량의 차이로 인해 유달율이 1 이 넘어가는 경우도 있었 다. 하지만 총량 기준유량 조건인 저수량 및 평수량 조건에 서는 $\mathrm{BOD}, \mathrm{T}-\mathrm{N}, \mathrm{T}-\mathrm{P}$ 의 유달율이 1 을 넘지 않고 적정범위 에서 산정되었으며 도출된 회귀식의 결정계수 $\left(\mathrm{R}^{2}\right)$ 가 $\mathrm{T}-\mathrm{N}$ $0.90, \mathrm{BOD} 0.53$, T-P 0.50 순으로 나타나 회귀식의 적용성 은 높은 것으로 판단된다.

2) 도출된 유달회귀식을 활용하여 식 (2) 형태의 평균유 달율과 식 (3) 형태의 기준유량 조건의 유달율 산정결과를
비교하였다. 식 (2)는 점, 비점 배출부하량과 상관없이 유 량-면적비 $(\mathrm{Q} / \mathrm{A})$ 에 의해 유달율이 결정되는 반면, 식 (3)의 유달율 결과는 점과 비점 배출부하량의 비율에 따라 유달 율이 다르게 산정되었다. 따라서 따라서 다양한 점, 비점 배출부하량의 개발 - 삭감 시나리오를 적용하는 총량제 수 질모델 적용시에는 식 (3)의 적용이 합리적일 것으로 판단 된다.

3) 식 (3)과 식 (2)에서 제시한 유달율 산정식의 차이를 배출계수와 연계하여 보다 명확한 적용성 평가를 위해 수 질모델을 구축하고 배출계수 적용 시나리오별 유달부하량 과 수질모델 입력자료를 4개 Case로 나누어 비교·분석하 였다. 그 결과, 유달율 회귀식은 식 (2)와 식 (3) 모두 사용 가능하나, 배출계수 적용에 따라 방법론을 달리할 필요가 있을 것으로 나타났다. 식 (2)를 사용할 경우는 배출계수를 저수량, 평수량 구분없이 1 로 동일하게 사용해야 하며, 식 (3)을 사용할 경우는 기술지침에서 정한 배출계수(저수량 0.15 , 평수량 0.5$)$ 를 적용해야 합리적인 수질모델 입력자료 를 도출할 것으로 판단된다.

4) 결과를 종합적으로 평가하였을 때 현행 총량제에서 특 정유량조건의 배출계수를 적용하고 있기 때문에 Hwang 등 ${ }^{3}$ 이 제시한 식 (3)과 같은 기준유량 조건의 유달율 산정방안 은 총량제 계획수립 및 목표수질 설정 시 합리적인 적용방 안으로 판단된다. 또한 본 연구내용은 차기단계 총량계획 수립 및 목표수질 설정 시 유달율 산정의 기초자료로 활용 가능할 것으로 판단된다.

KSEE

\section{References}

1. Hwang, H. S., Rhee, H. P., Park, J. H., Kim, Y. S., Lee, S. J. and Ahn, K. H., "Study on Estimatioon and Application of Discharge Coefficient about Nonpoint Source Pollutants using Watershed Model," J. Korean Soc. Water Environ., 31(6), 653 664(2015).

2. National Institute of Environmental Research, "The technical guideline for Total water Pollutant Load Management System," NIER, NIER-GP2014-057(2014).

3. Hwang, H. S., Rhee, H. P., Ahn, K. H., Park, J. H., Kim, Y. S. and Lee, S. J., "A Study on Estimated Pollutant Delivery Load for the Basic Plan of TPLC," J. Korean Soc. Water Environ., 32(4), 375 383(2016).

4. Park, J. W., Kim, K. S., Hwang, K. S., Lee, Y. W. and Lim, B. J. "Application of Load Duration Using Discharge-Load Rating Curve at Jiseok Stream Watershed," J. Korean Soc. Water Environ., 29(4), 523 530(2013).

5. Choi, D. H., Jung, J. W., Lee, K. S., Choi, Y. J., Yoon, K. S., Cho, S. H., Park, H. N., Lim, B. J. and Chang, N. I., "Estimation of Pollutant Load Delivery Ratio for Flow Duration Using L-Q Equation from the Oenam-cheon watershed on Junam Lake," J. Environ. Sci., 21(1), 31 39(2012). 
6. Jung, J. W., Lim, B. J., Choi, D. H., Choi, Y. J., Lee, K. S., Kim, Y. J., Kim, K. S., Chang, N. I. and Yoon, K. S., "Evaluation of Flow-Pollutant Load Delivery Ratio Equation on Main Subwatersheds within Junam Lake," J. Environ. Sci., 21(10), 1235 1244(2012).

7. Park, J. H., Hwang, H. S., Rhew, D. H. and Kwong, O. S., "Estimation of Delivery Ratio Based on BASINS/HSPF Model for Total Maximum Daily Load," J. Korean Soc. Water Environ., 28(6), 833 842(2012)

8. Kang, J. H., Hong, J. J., Kim, S. G., Son, M. S., Lee, Y.
J. and Lim, B. J., "A Study Calculating of Delivery Ratio Daily WinHSPF/BASINS Model," J. Korean Soc. Water Sci. and Technol., 18(5), 19 28(2010).

9. Gyeongsanbuk-do., "The Third Stage Basic Plan of Gyeongsanbuk-do TMDL in Nakdong River," Gyeongsanbuk-do (2015).

10. Shon, T. S., Park, J. B. and Shin, H. S., "A Study on Estimation of the Delivery Ratio by Flow Duration in a SmallScale Test Bed for Managing TMDL in Nakdong River." $J$. Korean Soc. Water Qual., 25(5), 792 802(2009). 